\title{
Sentiment Analysis Challenges of Informal Arabic Language
}

\author{
Salihah AlOtaibi \\ Information Systems Department, \\ College of Computer and Information Sciences \\ Al Imam Mohammad Ibn Saud Islamic University (IMSIU) \\ Riyadh, KSA
}

\author{
Muhammad Badruddin Khan \\ Information Systems Department, \\ College of Computer and Information Sciences \\ Al Imam Mohammad Ibn Saud Islamic University (IMSIU) \\ Riyadh, KSA
}

\begin{abstract}
Recently, there are wide numbers of users that use the social network like Twitter, Facebook, MySpace to share various kinds of resources, express their opinions, thoughts, messages in real time. Thus, increase the amount of electronic content that generated by users. Sentiment analysis becomes a very interesting topic in research community. Thereby, we need to give more attention to Arabic sentiment analysis. This paper discusses the challenges and obstacles when analyze the sentiment analysis of informal Arabic, the social media. The most of recent research sentiment analysis conduct for English text. Also, when the research works in Arabic sentiment analysis, they focus in formal Arabic. However, most of social media network use the informal Arabic (colloquial) such as Twitter and YouTube website. This paper investigates the problems and the challenges to identify sentiment in informal Arabic language which is mostly used when users express their opinions and feelings in context of twitter and YouTube Arabic content.
\end{abstract}

Keywords-Informal Arabic; Sentiment analysis; Opinion Mining (OM); Twitter; YouTube

\section{INTRODUCTION}

Arabic is a Semitic language spoken by more than 330 million people as a native language. Arabic is a highly structured and derivational language, in which morphology has a very important role. Thus, Arabic natural language processing (NLP) applications must deal with the complex nature of the Arabic language. For example, Arabic is written from right to left and no capitalization is used for nouns, which is a necessary feature in text mining. The Arabic language contains 28 letters and, in addition, the Hamza (s). In Arabic, letters change their shape according to their position in the word (beginning, middle, or end) [1]. For example, see letter "ي/ya'a" and letter "ج/geem," as shown in Table I.

TABLE I. POSITION OF THE CHARACTER IN THE WORD

\begin{tabular}{|c|c|c|c|}
\hline Letter & Beginning & Middle & End \\
\hline$ي$ & $\rightarrow$ & $\succ$ & - \\
\hline$ج$ & $\rightarrow$ & - & $ج$ \\
\hline
\end{tabular}

Arabic is the official language of Islam and of the last Prophet. It was selected to be the language of the Holy Qur'an. Muslims living throughout the world, thus, feel an affiliation with the Arabic language[1].

\section{A. Types of arabic}

There are three types of Arabic: Classical Arabic language
(CA), Modern Standard Arabic language (MSA), and informal Arabic language (the latter is sometimes referred to as colloquial Arabic language).

$\mathrm{CA}$ is the language of Islam, which Arabic speakers use in their prayers and when reading the Qur'an. MSA is the official language across the Arab world. It is used by educated people in more formal circumstances; for example, for news reports, in classrooms, and in business. Informal Arabic is the language that people speak daily with family and friends, in which people also use their own dialects, which vary from region to region. The three different styles of Arabic language are available to every Arab - for example, each day, an Arabic speaker will use Classical Arabic for his five daily prayers, MSA when listening to or reading the news, and his/her own dialect when at home. Each type of Arabic has its own grammar, lexicon, and morphology, although though some properties are shared between the varieties. Most existing research tools have been developed to handle text that is written in MSA. This constitutes a limitation when it comes to research that focuses on text mining in relation to informal Arabic language [1], [2], [3].

In the research field, the sentiment analysis becomes hot topic to work in. The most of research and techniques for sentiment analysis is for English text. Thereby, it is obvious, there are limitations in the researches that interest for sentiment analysis for Arabic language [4]. Moreover, most of the researchers focus on formal Arabic language [5]. Since most of users use informal Arabic in the world of social media, the task of sentiment analysis becomes more sophisticated [6]. This motivates us to explore the challenges to analyze the sentiment for informal Arabic language such the different Arabic Dialects are another challenge.

The paper is organized in few sections to describe further details of our work. Section 2 describes the nature and the complexity of Arabic language. Section 3 gives overview about the main commons and differences between informal Arabic and informal English. Section 4 gives overview about the challenges in sentiment analysis for Arabic language. In section 5, outlines the related work done in this area. In section 6, gives overview about the main commons and differences between Twitter and YouTube dataset. In section 7, we describe the method and the preprocessing. Section 8 shows our finding and discussion. Finally, in the brief Section 9, we make concluding remarks. 


\section{THE COMPLEXITY OF ARABIC LANGUAGE}

The Arabic language is challenging and complex due to its nature and characteristics. The following paragraphs illustrate the complexity of Arabic.

This section provides a literature review for the field of sentiment and semantic analysis, focusing mainly on informal Arabic language.

\section{A. Word meaning}

The term "word" defines a single, isolated item between two spaces, which has a certain meaning. In Arabic, it is common for one word to have several different meanings, depending on the context. Table II gives the example of the Arabic word wـ/sahel, which can be used as a noun with three different meanings. The phrases have been taken from Twitter [7].

TABLE II. MEANINGS OF THE WORD سكل/SAHEL AS A NOUN

\begin{tabular}{|c|c|c|}
\hline Sentences & Phrases in English & Word Meaning \\
\hline $\begin{array}{c}\text { سهل منبسط } \\
\text { sahel moonbaset }\end{array}$ & "flat plain" & Flat floor \\
\hline $\begin{array}{c}\text { سهل بن سعد } \\
\text { Sahel bin Saad }\end{array}$ & "Sahel bin Saad" & Name \\
\hline 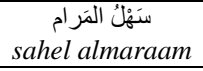 & "easy to get" & Easy \\
\hline
\end{tabular}

\section{B. Variations in lexical category}

In Arabic linguistics, a word can be a noun, verb, or particle. The term "particle" covers all other words that are not nouns or verbs, such as prepositions and conjunctions, for instance. Examples are given in Table III.

TABLE III. WORD TYPES IN THE ARABIC LANGUAGE

\begin{tabular}{|c|c|c|}
\hline Word Type & Example & English Translation \\
\hline Noun & كتاب & Book \\
\hline Verb & على & Write \\
\hline Particle & على & On \\
\hline
\end{tabular}

Moreover, a word can belong to different lexical categories, depending on the context. Table IV shows how the word حلق/halq can be used in different parts of speech [7].

TABLE IV. LEXICAL CATEGORIES FOR THE WORD حلق/HALQ

\begin{tabular}{|c|c|c|c|}
\hline Phrases & Phrases in English & $\begin{array}{c}\text { Word } \\
\text { Category }\end{array}$ & $\begin{array}{c}\text { Word } \\
\text { Meaning }\end{array}$ \\
\hline $\begin{array}{c}\text { حلق الانسان } \\
\text { halq alensan }\end{array}$ & "human throat" & Noun & Throat \\
\hline 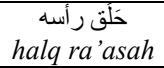 & "shaving his head" & Verb & Shaving \\
\hline $\begin{array}{c}\text { حَلْقَ الطائرُ } \\
\text { halq alta'er }\end{array}$ & "flying bird" & Verb & Fly \\
\hline
\end{tabular}

\section{Morphological characteristics}

Morphology is a branch of linguistics that deals with the structure of words. It concerns word formation, roots, and affixation behaviors. Arabic is a highly structured and derivational language. Arabic is a Semitic language and it is morphologically complex. Typically, a word in a Semitic language contains more information than a word in a nonSemitic language like English.
In Arabic, for example, various affixes can be attached to create new words; from the root word درس /darasa, for instance, several different words can be generated, such as يدرس/yadras ("studying" in English), مدرس/modras (English: "teacher"), مدرسة "school"), and مدارس/madares (English: "schools") [8]. Below is short description of each basic item in the Arabic language.

As clarified above, a word is a single, isolated item with a certain meaning. In Arabic, a word can be a noun, verb, or particle, and the same word can fit into different categories, depending on the context.

A morpheme is the smallest linguistic unit that has a meaning. A morpheme cannot be split into smaller units. Morphemes should give a meaning to the word of which they are a part.

A root is a single morpheme that provides the basic meaning of a word. In Arabic, the root is the original form of the word, before any transformation process occurs. Many words can be formed using one root.

A stem is a morpheme without an affix. The stem provides a specific idea or meaning. In English, the root is also sometimes called the "stem" or "word base," but in Arabic, the stem (or base) is different from the root [7]. Table V illustrates the morphological characteristics of Arabic.

TABLE V. MORPHOLOGICAL CHARACTERISTICS

\begin{tabular}{|c|c|c|}
\hline $\begin{array}{l}\text { Morphological } \\
\text { characteristics }\end{array}$ & Definition & Example \\
\hline Word & $\begin{array}{c}\text { a single and isolated item } \\
\text { between two spaces }\end{array}$ & $\begin{array}{c}\text { المحمدون/alMuhamm } \\
\text { adwn }\end{array}$ \\
\hline Morpheme & $\begin{array}{l}\text { smallest linguistic unit that } \\
\text { has a meaning }\end{array}$ & / / Wn \\
\hline Stem & The basic form of word & /Muhammad \\
\hline Root & The original form of word & /حمد/Hammd \\
\hline
\end{tabular}

An affix is a morpheme that can be added before (prefix), after (suffix), or within (infix) the root or stem to give a new / سجد Sajed can have different meanings when various affixes are added.

TABLE VI. DIFFERENT MEANINGS OF سجد/ SAYED WHEN DIFFERENT AFFIXES ADDED

\begin{tabular}{|c|c|c|c|c|}
\hline Word & $\begin{array}{c}\text { English } \\
\text { translation }\end{array}$ & Suffix & Infix & Prefix \\
\hline & "Prostrate" & $* * *$ & 1 & $* * *$ \\
\hline /مسجد Msadjad /مسد & "Msadjad" & $* * *$ & *** & م \\
\hline سجادة & "Carpet" & دة & 1 & $* * *$ \\
\hline
\end{tabular}

In text mining, the stemming process is usually used to convert a word into its root form. The main objective of the stemming process is to remove all possible affixes, thus diminishing the complexity of a word and reducing the number of features and tokens in corpora [7]. For example, if the words ذاهبون/thahebon, ذهبو/thahabo, andhab are all in a corpus, after the stemming process has taken place, all the words will be recognized in the text mining procedure as the same word اذذب الـhhab ("go" in English). However, the stemming process is not always considered beneficial in 
Arabic because the Arabic root is context dependent; thus, a stem may lead to more than one definition [9]. Table VII exemplifies words with different meanings that share a common root.

TABLE VII. DIFFERENT WORDS WITH THE SAME ROOT

\begin{tabular}{|c|c|c|c|}
\hline Sentences & English translate & Root & Meaning \\
\hline $\begin{array}{l}\text { يخرج من المنزل } 1 \text { akrooj men almanzel } \\
\text { yنl }\end{array}$ & "leaves home" & خرج & Goes out \\
\hline تخرج من الجامعه & $\begin{array}{l}\text { "graduates from } \\
\text { college" }\end{array}$ & خرج & Graduate \\
\hline
\end{tabular}

Vowelization or diacritization is the process of putting diacritical mark vowels above or under letters in Arabic words (fatha: , dammah: kasrah: ). Nunation is the process of putting a set of diacritically marked vowels at the end of a word to create the sound of the letter $\dot{ن} / N$. The kasheeda (-) or tatweel is the symbol used to stretch some Arabic characters [7]. The tatweel symbol is often used in informal Arabic language to emphasize a feeling or meaning. In the text mining process, the tatweel must be removed because it creates multiple forms of the same word. Table VIII shows how tatweel preformed different forms for one words.

TABLE VIII. TATWEEL

\begin{tabular}{|c|c|}
\hline Word & English translation \\
\hline مرحبا & \\
\hline مرحببــا & "hello" \\
\hline مرحبـ $\underbrace{}_{\text {marhaba }}$ & \\
\hline
\end{tabular}

\section{THE INFORMAL ARABIC VS. INFORMAL ENGLISH LANGUAGE}

Informal language could be described as language that ignores the standard rules of grammar and spelling. In general, the Arabic language is written from right to left, while English is written from left to right. There is no capitalization in Arabic, unlike in English [1].

Informal English uses abbreviations (for example, "m8" for "mate" and "u" for "you"), whereas in Arabic, there are no such abbreviations. In informal Arabic language, abbreviations called Arabization are used (like برب for "be right back" and لول for "laughing out loud"). Arabization is the process of translating new concepts and terminology into Arabic. In fact, with Arabization, users translate only the first letter of each word in the English phrase or sentence to create a new abbreviation in Arabic (so, using the previous example of "be right back," برب is "BRB"). The main commonalities between informal Arabic and informal English are the use of emoticons, texting-style abbreviations, and repeated letters or punctuation, which is added for emphasis [10].

\section{ARABIC SENTIMENT ANALYSIS CHALLENGES}

NLP for Arabic is fraught with many challenges, some of which result from the structural and morphological complexity of the language. As mentioned previously, Arabic is a derivational language, which means that many words can be formed from three-letter roots. The resulting words may look similar, but have very different meanings. Arabic grammar is also highly complex, containing a variety of sentence structures, both verbal and nominal. A verbal sentence is one that starts with a verb phrase, whereas a nominal sentence starts with a noun phrase. Arabic also contains many word forms and diacritics [1], [4]. The complex features of the language make the task of analysis more difficult [11]. Furthermore, the semantic dictionaries or lexicons on offer for Arabic text analysis are limited. Indeed, future research should consider the necessity of creating morphological analysis tools for Arabic text analysis that can cover all word forms and can perform suffix, affix, prefix, and root extraction. Grammatical analyzers and/or part-of-speech (POS) taggers are also needed. Some morphological analyzers have been developed for use with the Arabic language, such as BAMA (the Buckwalter Arabic Morphological Analyzer) and MADA (the Morphological Analysis and Disambiguation for Arabic analyzer). There are no sophisticated POS taggers and lexicons tools in Arabic which identify all parts of speech and discover the difference of sentence's types. These issues present a challenge for sentiment mining, which generally requires both semantic analysis of words and grammatical analysis of text [4].

In fact, another major challenge that has surfaced due to the emergence of social media is that most of the Arabic language found on the internet is written in informal Arabic. The informal version of the language is unstructured in nature. Furthermore, many users utilize their own regional dialects, rather than opting for modern standard Arabic; for instance, the word شوف/shoof, which means "look" in English, might be used instead of the word أنظر/onther. Another important point is that informal Arabic does not use diacritics; thus, in some cases, the meaning of the word becomes ambiguous. For example, the words مَدَرِّسة ("teacher") and (مَذْرسَة ("school") look the same when written without diacritics (مدرَّة ("مَّة (مدرة). Social media has also given rise to the increased usage of letter repetition to emphasize the meaning or feeling associated with a word (IIIIII شكر - "thankssss," as opposed to - "thanks") [12].

Informal Arabic words usually do not have their own specific roots. Indeed, a stemmer will sometimes identify the same root for both the informal word and the formal word, as is the case with the terms راحه/rahaah (formal) ("comfort" in English), and نروح /nrooha (informal) ("go" in English), both of which take the root $ح$ /rooh [13]. Another key trait in Arabic social media is the use of compound phrases and idioms to express opinions; e.g., با ولد يا مطوع/ya walad ya motaua (a negative expression that belittles someone pretending to be religious). Compound phrases and idioms vary from one country to another. Also, that gives different sentiment polarities rather than its constituent words itself. According to previous examples, the sentiment polarity is negative while none of its constituent words are negative [14].

As most social media users utilize informal Arabic, the task of text analysis therefore becomes more challenging. The introduction of various dialects poses a further difficulty [6] as does the lack of literature on informal Arabic language [5]. These factors motivated us to focus on the problems that exist in informal Arabic, with the aim of encouraging more researchers to participate in this field. 


\section{RELATED WORK}

Sentiment analysis depends on using various techniques of machine learning, such as Knowledge-based, corpus-based, Naïve Bayes (NB), support vector machine (SVM) and maximum Entropy model (ME). Sentiment analysis can be applied on different types of content such as content of newspapers, review sites, tweets from twitter site [15].

\section{A. Sentiment analysis on Arabic Content}

The sentiment analysis for Arabic language became topic of interest for many researches to participate in this field. In one study, researchers presented an advanced technique for inferring sentiment orientation of social media sites focusing on the problems related to web dependent analysis [16]. New tool was developed that can be used for Arabic sentiment analysis. The proposed tool is divided into two techniques; NLP and human computation. The proposed system consists of two parts; game-based lexicon and sentiment analyzer parts. The first part is used to build the lexicon based on human computation, while the second part is a sentiment analyzer that takes each review and executes sentences segmentation [5].

Other researchers proposed a new technique for Sentiment Analysis and Subjectivity Analysis (SSA) for certain Arabic social media sites. Results demonstrated that the use of lexeme or lemma data is useful. On the other hand, there is a need for individualized solutions for every task and genre [8]. Also, there is research work performed to do the sentiment analysis for Arabic Facebook news pages. They used three machine learning classification techniques; Naive Bayes, SVM and decision tree are used to improve the sentiment analyzer [17]. Some researchers also, proposed a technique for extracting and analyzing Arabic business reviews that are available in forums and blogs. The system has two basic parts; reviews classifier and sentiment analyzer. First part classifies the web page. Second part for detecting the polarity of the sentences based on an Arabic lexicon [18]. In 2012 an advanced Arabic sentence level sentiment categorization technique was introduced that depends on two methods; a grammatical and semantic methods. [19].

\section{B. Arabic Sentiment analysis on twitter}

As we mentioned in previous paragraphs, the research on Arabic semantic is limited. One of those limited studies was provided by A. Shoukry and A. Rafea. They produce an application on Arabic sentiment analysis by classification the Arabic tweets. They used different ML classifiers and different features. They apply the SVM and naïve bayes and also try the combinations of classifiers [3]. Also, other researchers tried to find and explore the problems of sentiment analysis for informal Arabic. They apply their experiments on twitter. They use knowledge-based technique. There is a limitation in the number of Arabic sentiment lexicons, and the main challenge is to build lexicons for informal words [13].

\section{TwitTer Data Vs. YouTube DATA}

Twitter is a microblog and social network that allows users to share their thoughts and express their opinions through short massages. While YouTube is a website designed for sharing video. In YouTube the users can restrict who views their videos with YouTube's privacy option. Also the users can post a comment and reviews on the videos that were viewing. There is some common and different between Twitter and YouTube Arabic text.

The most commons between Twitter and YouTube users' post are all of the users use informal language that ignores the standard rules of grammar and spelling. Also the posts contain emoticons, texting-style abbreviations, and repeated letters or punctuation added for emphasis.

The main differences, on Twitter, users produce short pieces of information known as "tweets" (limited to 140 characters). One can find a diverse range of topics within these tweets. Twitter users may post tweets expressing opinions about personalities, politicians, products, companies, and events, for instance [20], [21], [22]. Furthermore, some of the symbols used in tweets are language-independent. For example, "@" is utilized when users are referring to other users. "\#” (hash tag) is used to mark topics or keywords - it is used to make messages more visible to other people. "RT" (retweet) is used when someone likes a tweet and wants to repeat it for their followers to see. The writing technique for tweets is fast and short. Users utilize acronyms and emoticons to express their opinions.

On YouTube, users produce reviews and opinions on contains of videos. There is no limited length for reviews posts. The posts only reviews or comment on contains of videos unlike the twitter tweets. There are no special symbols used in reviews like tweets.

\section{METHOD}

This paper aims to investigate the problem and challenges of informal Arabic sentiment analysis. In this paper, we used twitter and YouTube datasets. The processing of the method can be described as follows: 1) after collecting the datasets, we determine the annotation of each tweets and each YouTube review (positive, negative, and neutral). 2) Convert the emotion icons to text. 3) Clean the dataset by removing: names, URL, pictures, English word, for tweets re-tweets sign, hash tags. 4) Normalizing process which makes the text in consistent form, in other words, convert all different forms of word to a common form. 5) Tokenization process applied on each tweets to divide them into multiple tokens based on whitespaces characters. 6) Then make stemming process to return each word to its root. 7) Remove the Arabic stop-word. The result of preprocess is used as input to the classifier model to test the result. The sentiment classifier used in the model is Naïve Bayes algorithm.

\section{FINDINGS AND DISCUSSION}

Informal Arabic language, in general, is "noisy" and poorly structured. It also features the non-standard repetition of letters, abbreviations, and emoticons, as well as the use of Arabized words.

Arabic tweets and YouTube reviews contain incorrect and misspelled word(s). These spelling problems needs special attention and require proper cleaning. When applying sentiment analysis for informal Arabic many problems occurred in text processing step. There are various problems 
that were found in each text processing phase. The following sub-sections expound the problems in each phase:

\section{A. Tokenization phase}

When applying sentiment analysis for informal Arabic many problems were encountered. The problems explained as following

\section{1) Repetition Letters}

The first problem is the repetition of letters, as mentioned in section 4. As we know that in the Arabic language if we have repeated letters in the text it cannot occur more than twice. So if the repetition exists at beginning, middle or at the end of the word more than two times, it will be detected in the pre-processing step. Unfortunately, repetition cannot be detected where a letter is repeated only twice. Table IX shows pre-processing of tweets with repetition letters. In literature issue of detection of the repetition is discussed for situation with repetition only existing at the end of word [13].

TABLE IX. REPETITION LETTER PROBLEM

\begin{tabular}{|c|c|c|c|}
\hline Platform & Sentences & $\begin{array}{l}\text { English } \\
\text { Translate }\end{array}$ & $\begin{array}{l}\text { After pre- } \\
\text { Processing }\end{array}$ \\
\hline Twitter & $\begin{array}{l}\text { كئيب ل ابععبععد حد } \\
\text { Kaeeb le abeeed } \\
\text { haad }\end{array}$ & $\begin{array}{l}\text { I am very } \\
\text { depressed }\end{array}$ & كئبب ل ابعدد \\
\hline Twitter & $\begin{array}{l}\text { (: جميل جداً } \\
\text { hahahahah Jamel } \\
\text { jeedan :) }\end{array}$ & $\begin{array}{l}\text { Very } \\
\text { beautiful :) }\end{array}$ & (: هه جميل جدا \\
\hline YouTube & أحسسسسسسسسسسسن & Better & أحسسن \\
\hline YouTube & $\begin{array}{l}\text { بالصر احة مرة واووووووو } \\
\text { beSaraha Marra } \\
\text { wowwwww }\end{array}$ & $\begin{array}{l}\text { In fact it is } \\
\text { wow }\end{array}$ & بالصر احة مرة \\
\hline
\end{tabular}

2) Negations

The second problem is that word polarities are affected significantly by ignoring negations like L/Ma, V/Laa, الم/lam, and $\mathrm{j} /$ lan which are formal Arabic negations. The informal Arabic contains many of informal negation words like $/$ مu $/$ Muo, موب Moub, which also affect the text polarities by converting the meaning of the sentence to exactly the opposite. Furthermore, as we mentioned in section 3, the informal Arabic used Arabized words. The Arabized words "نوت" "نو " which means in English "no" and "not", are also used as negations words in informal Arabic. Table $\mathrm{X}$ shows how the informal negation words affected the text polarities.

A negation indicator should, therefore, be used to detect polarities accurately.
TABle X. Who Negations AfFect the TeXt Polarities

\begin{tabular}{|c|c|c|c|c|c|}
\hline Platform & Sentences & $\begin{array}{c}\text { English } \\
\text { Translate }\end{array}$ & Polarities & $\begin{array}{c}\text { Sentences } \\
\text { Without } \\
\text { Negation }\end{array}$ & Polarities \\
\hline Twitter & $\begin{array}{l}\text { مش أهبل : } \\
\text { Mush } \\
\text { Ahbal }\end{array}$ & Not idiot & positive & أهبل :) & negative \\
\hline Twitter & 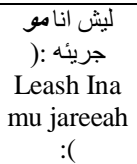 & $\begin{array}{l}\text { Why I am } \\
\text { not bold }\end{array}$ & negative & جريئه :) جل & positive \\
\hline Twitter & $\begin{array}{c}\text { نوف يفهم شي } \\
\text { No yefham } \\
\text { shee }\end{array}$ & $\begin{array}{c}\text { Does not } \\
\text { understand } \\
\text { something }\end{array}$ & negative & يفهم شي & positive \\
\hline YouTube & $\begin{array}{c}\text { ذو ملاهي } \\
\text { Mu malahe } \\
\text { thee }\end{array}$ & $\begin{array}{c}\text { This is not } \\
\text { amusement } \\
\text { park }\end{array}$ & negative & ملاهي ذيب & positive \\
\hline YouTube & $\begin{array}{c}\text { اناموب طفل } \\
\text { Ana moub } \\
\text { teffel }\end{array}$ & $\begin{array}{l}\text { I am not a } \\
\text { child, }\end{array}$ & Positive & انا طفل انا 14 سنه & negative \\
\hline
\end{tabular}

3) Connecting different words together

The third problem involves Twitter users connecting different words together-this method of writing occurs frequently in tweets because the length of a tweet is limited. This issue affects stop-word filtering because certain stop words are not removed and new forms of words are created. Table XI illustrate how this problem affects the pre-processing step by increasing the number of tokens

TABLE XI. THE EFFECT OF CONNECTING DifFERENT WORDS TOGETHER AT TOKENIZATION AND STOP WORDS FALTERING

\begin{tabular}{|c|c|c|c|c|}
\hline $\begin{array}{l}\text { Tweet } \\
\text { Problem }\end{array}$ & Sentences & $\begin{array}{l}\text { English } \\
\text { Translate }\end{array}$ & $\begin{array}{l}\text { Tokenizing } \\
\text { Process }\end{array}$ & $\begin{array}{l}\text { Falter Stop } \\
\text { Word }\end{array}$ \\
\hline $\begin{array}{l}\text { Tweet } \\
\text { contain } \\
\text { connecting } \\
\text { words } \\
\text { together }\end{array}$ & 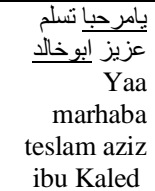 & \multirow{2}{*}{$\begin{array}{l}\text { Hello, thank } \\
\text { you Ibu } \\
\text { Kaled, you } \\
\text { are dear and } \\
\text { precious } \\
\text { person }\end{array}$} & تبامرحبا & تسلم تيز \\
\hline $\begin{array}{l}\text { Tweet does } \\
\text { not contain } \\
\text { connecting } \\
\text { words } \\
\text { together }\end{array}$ & 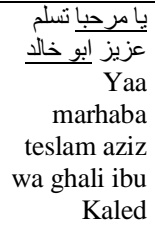 & & تِيا تِليا & نرخلم \\
\hline
\end{tabular}

From the table above, shows the results of tokenization process and faltering the stop words are different based on how the tweet is written. 
Connecting different words together can also cause ambiguities in meaning like words ووفي/wafee and هم/whm have two different meanings with/without connection as can be seen in Table XII.

TABLE XII. THE CONNECTING DIFFERENT WORDS TOGETHER CAUSE AMBIGUITIES IN MEANING

\begin{tabular}{|c|c|c|c|c|}
\hline Platform & Sentences & $\begin{array}{l}\text { English } \\
\text { Translate }\end{array}$ & Word & Meaning \\
\hline Twitter & $\begin{array}{l}\text { تبتسم : () . وفي عبنيك ألفة } 2 \text { دمعة } \\
\text { Tebtassen wafee } \\
\text { Eaneek alf damaah }\end{array}$ & $\begin{array}{l}\text { Smiling :)). } \\
\text { and Thousands } \\
\text { of tears in your } \\
\text { eyes }\end{array}$ & و وفي & And in \\
\hline Twitter & $\begin{array}{l}\text { قلبي وفي . ماني مثل غيري } \\
\text { Galbe wafee mane } \\
\text { methel garre }\end{array}$ & $\begin{array}{l}\text { I have the loyal } \\
\text { heart .. I am } \\
\text { not like the } \\
\text { other }\end{array}$ & وفي & Loyal \\
\hline Twitter & 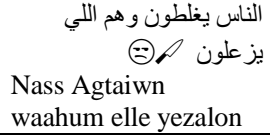 & $\begin{array}{l}\text { people make } \\
\text { mistakes and } \\
\text { also they } \\
\text { Angry }\end{array}$ & 2 & And they \\
\hline Twitter & $\begin{array}{c}\text { وهمو حيره } \\
\text { Waham waa heera }\end{array}$ & $\begin{array}{c}\text { Illusion } \\
\text { and confusion }\end{array}$ & 9 & worry \\
\hline YouTube & $\begin{array}{l}\text { وهم مايعترفو ا بفشلهم } \\
\text { Waa hom Mayereefo } \\
\text { be fashalho }\end{array}$ & $\begin{array}{l}\text { They did not } \\
\text { admit for they } \\
\text { failing }\end{array}$ & son & And they \\
\hline YouTube & $\begin{array}{c}\text { وفي مقاطع فيديو رعب fee makateea } \\
\text { video roob }\end{array}$ & $\begin{array}{l}\text { And in video } \\
\text { clips horror }\end{array}$ & و وفي & And in \\
\hline
\end{tabular}

\section{4) Diacritization problem}

The tokenization is performed based on finding whitespaces characters. Some types of punctuations like diacritic are removed and then add single space, so the word broken to many tokens. The problem was variations of word forms and diacritic. Table XIII shows the diacritic problems.

TABLE XIII. The Diacritic Problems During ToKeniZation Process

\begin{tabular}{|c|c|c|}
\hline Platform & $\begin{array}{l}\text { Tweet before } \\
\text { Tokenization } \\
\end{array}$ & $\begin{array}{l}\text { Tweet after } \\
\text { Tokenization } \\
\end{array}$ \\
\hline Twitter & 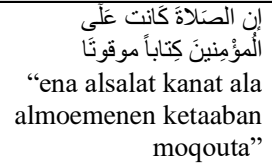 & إن مؤ م نين لاة كت انت موقو على \\
\hline Twitter & $\begin{array}{r}\text { راح انتُحرَ ساعدوني } \\
\text { "Raah Inteheer } \\
\text { saodony" }\end{array}$ & راح ان ت حـر ساعدوني \\
\hline
\end{tabular}

The problem of the deletion of diacritics and certain word forms, like tatweel cases, was discussed in section 2. The problem was solved in this study during the suggestion preprocessing stage. Table XIV shows the normalization cases that were used in pre-processing.

TABLE XIV. NORMALIZATION CASES

\begin{tabular}{|c|c|}
\hline Rule & Example \\
\hline Tashkeel & المؤمنين >_أُمؤْمِنِينَ \\
\hline Tatweel & اللهـ>_اللــــــ \\
\hline Alef & İor lor $!->1$ \\
\hline Heh & oor $\ddot{b}_{-}>$。 \\
\hline
\end{tabular}

\section{5) Emoticons problem}

Informal Arabic language text often uses emoticons, which cannot be interpreted by text-based models.
When the text was filtered to remove English words and special characters, all the emoticons were also removed. Thus, to preserve the emoticons, meaningful names were given to each symbol appearing in the corpus, which allowed the role of emoticons to be examined at sentiment analysis model. Table XV shows examples of the emotion icons conversion step.

TABLE XV. EXAMPLES OF THE CONVERTING EMOTION ICONS TO MEANINGFUL TEXT

\begin{tabular}{|c|c|c|c|c|}
\hline Platform & $\begin{array}{l}\text { Emotion } \\
\text { icons }\end{array}$ & Sentences & $\begin{array}{l}\text { English } \\
\text { Translate }\end{array}$ & $\begin{array}{l}\text { After } \\
\text { converting } \\
\text { the icons }\end{array}$ \\
\hline Twitter & • )': & $\begin{array}{l}\text { • )': : مع السلامه } \\
\text { "Maa alslamah } \\
\text { † )':" }\end{array}$ & Goodbye )': & رمع رمزين رمزلب \\
\hline Twitter & O_o & $\begin{array}{l}\text { O_o متردد } \\
\text { "Motaraded } \\
\text { O_o" }\end{array}$ & $\begin{array}{l}\text { Hesitant } \\
\text { O_o }\end{array}$ & رمز منفاجئ \\
\hline YouTube & (: & 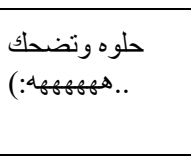 & $\begin{array}{l}\text { Sweet and } \\
\text { laugh (: }\end{array}$ & 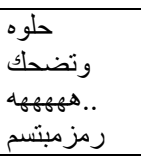 \\
\hline YouTube & $\cdot-$ & غبي ._. & Dumbass ._. & رمزمتفاجئ \\
\hline
\end{tabular}

6) Writing style in informal Arabic text

Some writing styles used in informal Arabic text can affect text pre-processing results, such as when a word is written inside another word, or write the word in separate letters to emphasize the meaning or feeling, as shown in Table XVI.

TABLE XVI. EXAMPLES OF WRITTEN STYLES USED IN INFORMAL ARABIC LANGUAGE, AND TOKENIZATION PROCESSING RESULTS

\begin{tabular}{|c|c|c|c|c|c|}
\hline Problem & $\begin{array}{l}\text { English } \\
\text { Transla- } \\
\text { tion }\end{array}$ & $\begin{array}{l}\text { Formal } \\
\text { Sentence } \\
\text { Style }\end{array}$ & $\begin{array}{l}\text { Tokeniz- } \\
\text { ation } \\
\text { Processin } \\
\text { g Results }\end{array}$ & $\begin{array}{l}\text { Informal } \\
\text { Sentence } \\
\text { Style }\end{array}$ & $\begin{array}{l}\text { Tokeniz } \\
\text {-ation } \\
\text { Processi } \\
\text { ng } \\
\text { Results }\end{array}$ \\
\hline \multirow{2}{*}{$\begin{array}{l}\text { Writing a } \\
\text { word } \\
\text { inside } \\
\text { another } \\
\text { word. }\end{array}$} & Welcome & $\begin{array}{l}\text { اهلا و سهلا } \\
\text { Ahlan wa } \\
\text { sahlam }\end{array}$ & سهلا & $\begin{array}{l}\text { اهـ وسهلا } \\
\text { Ahlan wa } \\
\text { sahlam }\end{array}$ & وسهلا \\
\hline & $\begin{array}{l}\text { Hello or } \\
\text { Aslam } \\
\text { alukom }\end{array}$ & $\begin{array}{l}\text { السلام عليكم } \\
\text { Aslam } \\
\text { alukom }\end{array}$ & عليكم & $\begin{array}{l}\text { السـ عليكم } \\
\text { Aslam } \\
\text { alukom }\end{array}$ & عـلام \\
\hline $\begin{array}{l}\text { Word } \\
\text { with } \\
\text { separate } \\
\text { letters }\end{array}$ & I finished & $\begin{array}{l}\text { أنا منتهية } \\
\text { Ana } \\
\text { Mentahea }\end{array}$ & منتهية & $\begin{array}{l}\text { أنامن هي Ana } \\
\text { Mentahea }\end{array}$ & $\begin{array}{l}\text { أنا } \\
\text { ن } \\
\text { م } \\
\text { م }\end{array}$ \\
\hline
\end{tabular}

\section{B. Filter Arabic stop words phase:}

There is no given stop word list for informal Arabic language which contain informal Arabic words like:

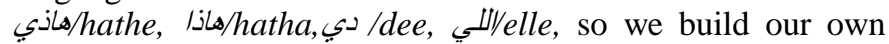
stop word list for informal Arabic language.

\section{Stemmer phase:}

In the Arabic there are different words with different meaning have the same root. This makes detecting the 
polarities of these words incorrect. As we mentioned above, in section 3 .

Also other problem occurs during the stemming process. The stemmer some time deleted some basic letters the word Table XVII shows the light stemmer problems. We remove the stemmer step from the text processing.

TABLE XVII. STEMMER DELETED SOME BASIC LETTER FROM THE WORD

\begin{tabular}{|c|c|c|c|}
\hline Platform & Sentences & $\begin{array}{l}\text { English } \\
\text { Translate } \\
\end{array}$ & $\begin{array}{l}\text { Stemmer } \\
\text { results }\end{array}$ \\
\hline Twitter & $\begin{array}{l}\text { القران الكريم AL Quran al Kareem } \\
\text { AL }\end{array}$ & $\begin{array}{l}\text { Koran } \\
\text { Kareem } \bullet\end{array}$ & قر > القران \\
\hline Twitter & $\begin{array}{l}\text { انزين انتهينا } \\
\text { Enzaeen entahena }\end{array}$ & $\begin{array}{l}\text { now we } \\
\text { finished }\end{array}$ & انز > انزين \\
\hline Twitter & $\begin{array}{l}\text { با الله ساعدني } \\
\text { Ya Allah saedney }\end{array}$ & $\begin{array}{l}\text { O God, } \\
\text { help me }\end{array}$ & له $\rightarrow$ الله \\
\hline YouTube & 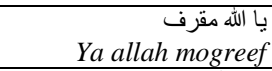 & $\begin{array}{r}\text { O God, } \\
\text { disgusting }\end{array}$ & له > الله \\
\hline YouTube & هذا فلم كرتون & $\begin{array}{r}\text { This film } \\
\text { carton }\end{array}$ & كرى >كرتون \\
\hline
\end{tabular}

\section{CONCLUSION}

The Arabic language is both challenging due to its complex linguistic structure and interesting because of its history and importance in religion, culture, and literature. Informal Arabic language, in general, is "noisy" and poorly structured. It also features the non-standard repetition of letters, abbreviations, and emoticons, as well as the use of Arabized words. Thus, these features should be considered during text mining. This paper investigates the problems and the challenges to identify sentiment in informal Arabic language in context of twitter and YouTube Arabic content. In this experiment, we found many issues that can be motivating for future research

\section{REFERENCES}

[1] A. Farghaly and K. Shaalan, "Arabic natural language processing: Challenges and solutions," ACM Trans. Asian Lang. Inf. Process., vol. 8, no. 4, p. 14, 2009.

[2] M. Korayem, D. Crandall, and M. Abdul-Mageed, "Subjectivity and sentiment analysis of Arabic: A survey," in Advanced machine learning technologies and applications, vol. 322, Berlin \& Heidelberg, Germany: Springer, 2012, pp. 128-139.

[3] H. Froud, A. Lachkar, and S. A. Ouatik, "Arabic text summarization based on latent semantic analysis to enhance Arabic documents clustering," Int. J. Data Min. Knowl. Manag. Process, vol. 3, no. 1, pp. 79-95, 2013.

[4] N. Farra, E. Challita, R. A. Assi, and H. Hajj, "Sentence-level and document-level sentiment mining for Arabic texts," in 2010 IEEE international conference on data mining workshops (ICDMW), 13 Dec. 2010, 2010, pp. 1114-1119.
[5] A. A. Al-Subaihin, H. S. Al-Khalifa, and A. S. Al-Salman, "A proposed sentiment analysis tool for modern Arabic using human-based computing," in Proceedings of the 13th international conference on information integration and web-based applications and services, 2011, pp. 543-546.

[6] A. Shoukry and A. Rafea, "Sentence-level Arabic sentiment analysis," in 2012 international conference on collaboration technologies and systems (CTS), 21-25 May 2012, 2012, pp. 546-550.

[7] I. A. Al-Sughaiyer and I. A. Al-Kharashi, "Arabic morphological analysis techniques: A comprehensive survey," J. Am. Soc. Inf. Sci. Technol., vol. 55, no. 3, pp. 189-213, 2004.

[8] M. Abdul-Mageed, M. Diab, and S. Kübler, "SAMAR: Subjectivity and sentiment analysis for Arabic social media," Comput. Speech Lang., vol. 28, no. 1, pp. 20-37, 2014.

[9] A. Moh'd Mesleh, "Support vector machines based Arabic language text classification system: Feature selection comparative study," in Advances in computer and information sciences and engineering, T. Sobh, Ed. Netherlands: Springer, 2008, pp. 11-16.

[10] M. Thelwall, K. Buckley, G. Paltoglou, D. Cai, and A. Kappas, "Sentiment strength detection in short informal text," J. Am. Soc. Inf. Sci. Technol., vol. 61, no. 12, pp. 2544-2558, 2010.

[11] P. Pak, Alexander and Paroubek, "Twitter as a corpus for sentiment analysis and opinion mining," Lrec, vol. 10, pp. pp. 1320-1326, 2010.

[12] R. M. Duwairi, R. Marji, N. Sha'ban, and S. Rushaidat, "Sentiment Analysis in Arabic tweets," in 5th international conference on information and communication systems (ICICS), 1-3 April 2014, 2014, pp. 1-6.

[13] L. Albraheem and H. S. Al-Khalifa, "Exploring the problems of sentiment analysis in informal Arabic," in Proceedings of the 14th international conference on information integration and web-based applications and services, 2012, pp. 415-418.

[14] S. R. El-Beltagy and A. Ali, "Open issues in the sentiment analysis of arabic social media: A case study," in 2013 9th international conference on innovations in Information Technology (IIT), 17-19 March 2013, 2013, pp. 215-220.

[15] A. Kumar and T. M. Sebastian, "Sentiment analysis on Twitter," Int. J. Comput. Sci. Issues, vol. 9, no. 4, pp. 372-378, 2012.

[16] R. Colbaugh and K. Glass, "Estimating sentiment orientation in social media for intelligence monitoring and analysis.," in 2010 IEEE international conference on intelligence and security informatics (ISI), 2010, pp. 135-137.

[17] A. E.-D. A. Hamouda and F. E. El-Taher, "Sentiment analyzer for Arabic Comments System," Int. J. Adv. Comput. Sci. Appl., vol. 4, no. 3, pp. 99-103, 2013.

[18] M. Elhawary and M. Elfeky, "Mining Arabic business reviews," in Data Mining Workshops (ICDMW), 2010 IEEE International Conference on, 2010, pp. 1108-1113.

[19] M. Abdul-Mageed and M. T. Diab, "AWATIF: A Multi-Genre Corpus for Modern Standard Arabic Subjectivity and Sentiment Analysis.," in LREC, 2012, pp. 3907-3914.

[20] K. Makice, Twitter API: Up and running: Learn how to build applications with the Twitter API. O'Reilly Media, Inc., 2009.

[21] L. Barbosa and J. Feng, "Robust sentiment detection on Twitter from biased and noisy data," in Proceedings of the 23rd international conference on computational linguistics: Posters, 2010, pp. 36-44.

[22] A. Go, R. Bhayani, and L. Huang, "Twitter sentiment classification using distant supervision," CS224N Proj. Report, Stanford, pp. 1-6, 2009. 